\title{
Not Getting Stuck in Dryness - Strategies for Coping with Phases of Spiritual Dryness Among Religious Brothers and Sisters in Germany —Findings from Qualitative Interviews
}

\author{
Mareike Gerundt $^{1}$ (D) $\cdot$ Yvonne Beerenbrock $^{1}$ D $\cdot$ Arndt Büssing $^{1}$ (D)
}

Accepted: 19 November 2021 /Published online: 14 January 2022

(C) The Author(s) 2022

\begin{abstract}
Many believers experience phases of spiritual dryness in their lives coupled with feelings of exhaustion, confusion, and emotional emptiness. Even religious sisters and brothers experience such phases. But how do they cope with phases of spiritual dryness, and what resources do they use to overcome them? In a qualitative study, 30 religious brothers and sisters utilized four main categories of resources: internal reflective resources, internal spiritual resources, external personal resources, and external other resources. A primary strategy does not seem to exist for overcoming phases of spiritual dryness. In the context of this study, therefore, several resources emerged that were used in accordance with the triggers and were applied against the background of the life situation, context and attitudes, perceptions, behavioral competencies, resources, and abilities of the person concerned.
\end{abstract}

Keywords Spiritual dryness $\cdot$ Religious order $\cdot$ Coping $\cdot$ Resources $\cdot$ Strategies · Qualitative study

Emotionally stressful situations are described as personal crises that cannot be adequately managed with the usual repertoire of action and reaction (Tugade et al., 2004). Experiencing spiritual dryness can be considered a spiritual crisis with varying intensity and duration in the lives of religious persons (Büssing \& Dienberg, 2019). During phases of spiritual dryness, the relationship with God is perceived as unstable for God is perceived as distant and even absent and one's prayer life as stale and fruitless - and God as not 'responding' (Büssing et al., 2013). Experiences of spiritual dryness therefore seem to contradict the concept of a fulfilling spiritual life, even though they are a fundamental part of it. Few religious persons

Mareike Gerundt

mareike.gerundt@uni-wh.de

Yvonne Beerenbrock

yvonne.beerenbrock@uni-wh.de

Arndt Büssing

arndt.buessing@uni-wh.de

1 Professorship Quality of Life, Spirituality and Coping, Faculty of Health, Witten/Herdecke University, 58313 Herdecke, Germany 
never experience such an episode, while many experience them occasionally (as a phase) or even recurrently (as long-lasting states or as a process; (Büssing \& Gerundt, 2020; Büssing et al., 2013, 2017a, b). Several seem to have found ways to cope with these phases, and when they overcome them, they often report an intention to help others even more and report experiencing greater spiritual serenity and depth (Büssing et al., 2017a, b).

However, clergy are often reluctant to describe their spiritual feelings or spiritual struggles (Kluitmann, 2008, p. 198; Leibold, 2019, p. 242) or to speak about the perceived absence of God and thus reveal that their source of faith seems to have run dry. German Bishop Heiner Wilmer warned that during such phases of spiritual dryness the "absence" of God should not be filled "with more emptiness" because this "is one of the most important desert lessons of all," namely, "to allow emptiness without losing confidence in fullness, that is infinitely difficult and at the same time infinitely central." He argues that no one simply 'has' God in terms of a magic buffer to fill all personal emptiness forever: "The fullness of God, that is the paradox, includes emptiness and its experience. Just as God becomes a person, the Great Small, so too is fullness in emptiness and emptiness in fullness" (Wilmer, 2018, p. 175).

In the German Pastoral Ministry Study (2012-2014) investigating quality of life, life satisfaction, job satisfaction, commitment, health, and spirituality, 763 Catholic priests identified their strategies for coping with spiritual dryness. ${ }^{1}$ Analysis of these Catholic priests' responses resulted in eight main categories of coping strategies: (1) explicit spiritual practice, (2) spiritual attitudes, (3) interpersonal communication, (4) diaconal action, (5) self-care, (6) avoidance strategies, (7) guided self-reflection and experience, and (8) other (Büssing et al., 2017a, b; Sautermeister et al., 2017). Religious brothers and sisters comprised almost $10 \%$ of the representative sample of all pastoral workers in the study. About $68 \%$ worked as priests and a total of $32 \%$ as deacons, pastoral assistants, and parish workers (Sautermeister et al., 2017). One of the main characteristics of religious people in the study was a higher expression in all dimensions of spiritual life, both in terms of frequency and strength of experience and in terms of resource strength of spirituality (Jacobs et al., 2016; Sautermeister et al., 2017).

Relying on the abovementioned strategies to cope with spiritual dryness, a survey of 620 members of the Seventh-day Adventist Free Church in Central Europe on their spiritual life and also on spiritual dryness (which they experienced with similar frequencies compared to Catholic pastoral workers; Büssing et al., 2020b) showed that commonly used strategies for coping with spiritual dryness were devotion, trust in God and personal prayer, and meditation and Scripture reading, followed by openness (to whatever may come), talking with others (i.e., family, friends), and self-care (i.e., leisure activities, sports, vacations) (Büssing et al., 2020c). Avoidance strategies or consulting a pastor or a psychotherapist were of lesser importance (Büssing et al., 2020c). Among the respondents, 15\% used strategies for coping with periods of spiritual dryness never or infrequently, 30\% sometimes (these were regarded as less effective strategies), 35\% frequently, and 19\% regularly (they were regarded as effective strategies).

During phases of spiritual dryness, the concrete experiences and their underlying causes and triggers are heterogeneous (Bussing 2019; Büssing et al., 2020a, b, c). Referring to Ignatius of Loyola (1491-1556), 'spiritual desolation' is a tempting by the evil spirit and a hint to change and re-order

\footnotetext{
1 The German Pastoral Ministry Study is a large-scale empirical-psychological research project in which more than 8,500 full-time pastoral care workers employed in the Catholic Church were surveyed by means of an extensive questionnaire on various aspects of their professional and spiritual identity.
} 
one's spiritual life (Ignatius of Loyola, 1914), whereas for John of the Cross (1542-1591) the 'dark night of the soul' is a process of spiritual purification in which God is the initiator (John of the Cross, 1959, 1962). For Evagrius Pontikus (345-399), these phases are a matter of bored negligence or 'inertia of the heart' termed acedia that affected Christian hermits living ascetic lives in the desert (Pontikus, 2007). However, spiritual dryness may be also related-at least in part - to states of depression and emotional exhaustion (Bäumer \& Plattig, 2010a; Büssing et al., 2017a, 2020a, b, c, Durà-Vilà, 2017; May, 2003; Ott, 1982).

We were interested to deepen the empirical findings, and thus we performed qualitative interviews with religious brothers and sisters regarding their specific lifestyle to gain more profound insight into their strategies and resources for coping with phases of spiritual dryness.

\section{Methods}

\section{Study design and participants}

This qualitative study explored the experience of and methods for coping with spiritual dryness. Semistructured interviews were conducted with 16 religious brothers and 14 religious sisters. The participants were informed about the study via emails, either directly or through their community or, in the case of religious brothers, through their superiors (who consented to this study). Inclusion criteria were living in a religious community, willingness to be interviewed anonymously, and written informed consent. To achieve heterogeneity, we enrolled brothers and sisters from different congregations and age categories as well as from larger and smaller communities.

The study was designed in two phases: religious brothers (14 Franciscan Capuchins, 2 Franciscans) were interviewed in 2017 and religious sisters (6 Franciscan sister, 1 Sister of Poor Clare, 3 Steyler Missionaries, 2 missionary Sisters of the Holy Heart of Jesus, 2 Dominican sisters) in 2019. The mean age of the 16 religious brothers was 64.7 [35-87] years; the mean duration of affiliation with their community was 40.4 [7-67] years. The mean age of the 14 religious sisters was 65.3 [40-82] years; the mean duration of affiliation with their community was 37.4 [11-61] years (Gerundt \& Büssing, 2020).

\section{Semistructured interviews}

Interviews were based on semistructured interview guidelines, starting with questions about general information (i.e., age, duration of affiliation with the religious order), followed by the main topics: (1) living in a religious community, (2) perception of God's closeness, (3) experience of spiritual dryness (experiences, triggers, coping strategies, etc.), (4) social connectedness, and (5) generativity. In this study, we focused on coping strategies for spiritual dryness.

All interviews were conducted in a familiar place, usually in a quiet room in the participant's community. Average duration of the interviews was 50-60 min. Interviews were audio-recorded and professionally transcribed. All identifying details were removed from the transcript. 


\section{Data analysis}

A group of four scientists from the fields of health sciences/medicine, cultural studies, and theology analyzed the German-language text material using qualitative content analysis techniques in accordance with Mayring (2008). The primary analysis started with interviews of the religious brothers (phase 1), first analyzing interview no. 1 and the first codes in depth. Then the next interviews were sequentially analyzed (in terms of meaningful text segments), and the set of codes was expanded according to the new content. These codes were summarized in a code list and grouped into main and subcodes according to their themes. With this preliminary list, all interviews were reanalyzed and the code list adapted accordingly.

Then, the interviews of religious sisters (phase 2) were analyzed using the same procedure. The religious sisters' codes were grouped in the code list of the religious brothers where possible, and new codes were added where appropriate. Finally, the interviews from phase 1 were reanalyzed using the adapted code list. Representative text passages served as anchor quotations for particular codes ("categories"). Only the representative text passages intended for publication were translated into English.

\section{Results}

During the content analysis process, the identified categories were inductively structured and condensed into four main topics with subcategories. These were structured as internal and external resources: (1) internal: reflexive resources, (2) internal: spiritual resources, (3) external: social resources, and (4) external: other resources (see Fig. 1). The categories will be further described with specific anchor quotations. To identify
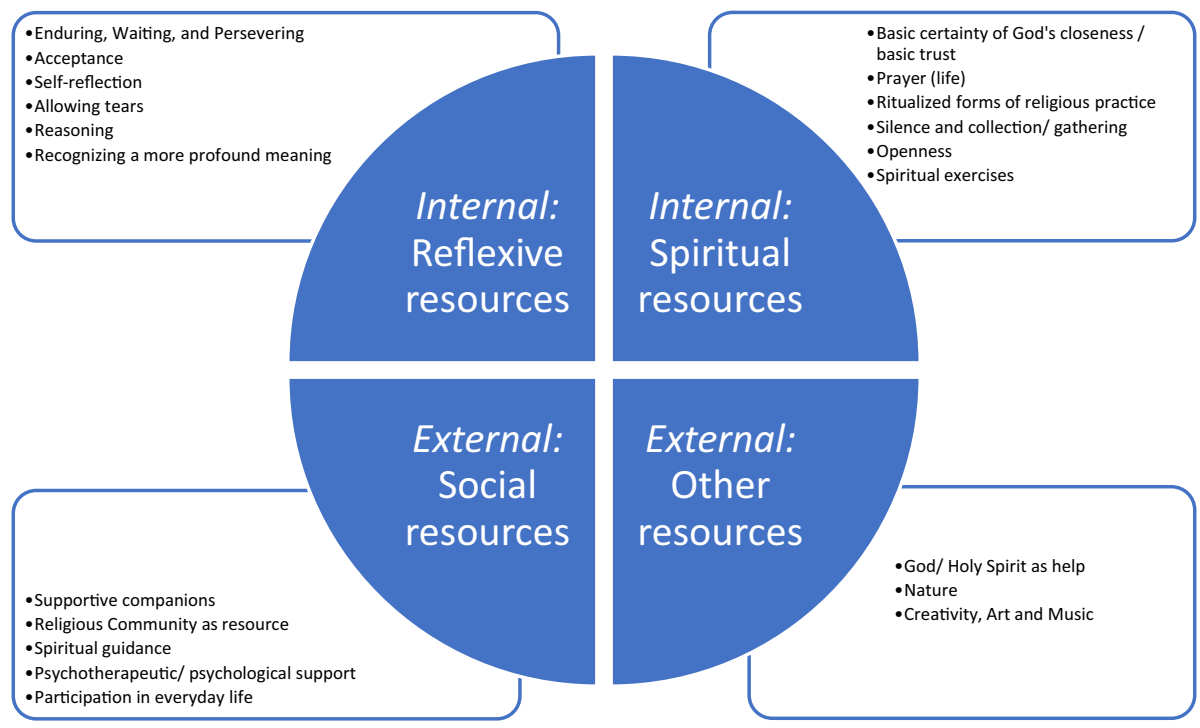

Fig. 1 Strategies for Coping with Spiritual Dryness Divided Into Four Main Topics and Subcategories 
quotes, we used B for a brother and $\mathrm{S}$ for a sister, followed by the number of the interview within the group and the number(s) of the line in the transcript.

\section{Internal: reflexive resources}

The first category comprises internal reflexive resources, including personality traits, attitudes, and specific coping skills in the subcategories enduring, waiting, and persevering; accepting; self-reflection; allowing tears; reasoning; recognizing a more profound meaning; and also a lack of coping strategies.

Enduring, waiting and persevering The attitudes of enduring, waiting, and persevering were mentioned in several interviews as coping strategies. The foremost strategy was to remain faithful to oneself and one's principles-even in the face of difficulties - and to "hold on, even when there is trouble, even when there is difficulty, hold on" (B3, 467). Keeping the faith is like having the "motivation to say, 'I want to stick with it somehow", (S14, 311-313). Faithfulness may also be found in the consistent following of Jesus Christ, "not slavishly, but because it belongs to my inner spiritual life. "So, if I want to continue to follow Jesus, I cannot cut myself off. And Jesus didn't choose the easier way either" (S8, 234-236). In faithfulness we may also find approval of God because "faithfulness is called for. Faithfulness is demanded, uh, and it also finds confirmation and approval" (B14, 349). In addition, the positive effects associated with the attitude toward faithfulness were noticed: "It was worth it to endure this dryness here, and also these doubts, also this fighting" (B2, 193-194). The support and encouragement of other brothers and sisters were beneficial: "the support of the sisters, who then said, 'Hold on, go ahead, try again and don't give up,' that simply helped me tremendously" (S4, 251-253). Encouragement by others may be categorized as an external social resource, too, but the point is that the struggling persons have to decide how to behave and whether to follow the recommendation to not give up.

In the analysis, we were able to compile different statements on the recourse to helpful coping patterns: "Well, I see now in retrospect, I find it nice, and that is also the experience to say through the years, 'Yes, that works, you can endure that' and many problems wereI tend very much to think a lot: What problems could come, if then this or that is? Don't worry so much [laughs], live the day and, yeah." (S12, 448-452).

The same applies to impulses from outside. In addition, written thoughts could stimulate reflection or meditation in terms of external resources that triggered internal processes: "But sometimes, something that led me further, or thoughts that came to me. Or if someone preached about it, I quickly wrote something down that spoke to me. I think those things carried me forward" (S8, 285-289). These thoughts were helpful for enduring the difficulties and when expecting a future change. "The free word that another gives me comes to me as something new, is a gift, is not just an activation of one's own inner being," is how Sudbrack (1982) describes meditation as an experience of the word that is spoken to one (p. 117).

Acceptance One category that emerged several times in the interviews with religious brothers was accepting their perceived distance from God. This cognitive coping strategy is acceptance that such phases are part of the life journey and of faith. For example, one brother emphasized not being able to avoid spiritual dryness because there were various 
distractions from the sacred throughout everyday life: "No, well, I can't avoid these-I can't avoid that, I can't" (B1, 214-215). However, this was not a matter of resignation but of accepting these phases as part of the spiritual life. One coping strategy was to manage sorrowful experiences of spiritual dryness as a phase on the journey of life and faith that was finite and that therefore one could get through: I realized that... what somehow comes along so badly on the first journey, and so ghastly and dry and cruel, that it is nevertheless only a phase" (B10, 280-282).

One religious sister describes actively seeking to change, but it was only at the point when she stopped being active that the feeling that God was drawing closer to her again emerged. She describes this experience as very moving and stronger than her previous doubt: "And at some point I gave up, and there-That was also interesting, when I then thought, okay, now I don't know any more either, then suddenly I had the feeling that God was moving. That shook me up completely. That shook me more than the whole mess before, because I-I still can't believe that today" (S3, 215-219). This process of accepting resembles a conversion rather than a simply accepting the situation as it is.

Cognitive acceptance of one's distance from God becomes apparent when experiencing the lack of God's closeness in prayer is free from the pressure of expecting that one has to "feel something." This seems to be unrealistic: "I also don't put myself under pressure to always feel something" (B3, 396). So, God's faithfulness may be felt especially in life crises: "You can't claim it, but when things get difficult and dicey for you, you will very clearly get an answer from Him" (B14, 340-342). However, the cognitive coping strategy of accepting the distance finds expression in the loss of the already experienced closeness of God: "So, I couldn't suffer from the night if I didn't know the light. And in this respect, the [quote] 'And must I also wander in the valley of the shadow of death, I fear no evil, for you are with me,' yes, belongs to it" (B16, 540). Thus, the experience of the dark valleys of life and dangers (a reference to Psalm 23:4) belongs to the faith journey accompanied by God.

Self-reflection The ability to engage in critical self-reflection is another subcategory. This is about evaluating one's own actions and thereby getting to know one's own resources, attitudes, and abilities and being able to use one's coping strategies in stressful situations. Reflecting on a stressful situation also allows one to investigate the underlying causes and makes it easier to recognize one's own stress level. A religious sister reports that she was driven (as encouraged by a spiritual counselor) to engage in reflection. This led to her becoming aware of the resources she had to steer her life in a new direction: "Yes, and somehow the longing or what that is, or this - then drives me again, yes, I also say, through the spiritual accompaniment, and that I again come to a point and think, what am I there for? What has given my life-yes, fullness? Where do I need to go again, and then sometimes you start small again, and sometimes those times last longer, sometimes shorter" (S9, 118-128). It is important to question oneself and to reflect: "How do I actually deal with myself? What am I contributing?" (B14, 380-381). In order to be able to overcome phases of spiritual struggles and doubt, the process of reflection seems to be beneficial: "Well, this reflection helps me to get out of doubt" (S13, 338).

Allowing tears Crying is a common way to express feelings of sorrow, grief, despair, hopelessness, relief, exhilaration, pride, and ecstasy (Hendriks, 2005). These are also the consequence of reflexive processes related to letting go of negative emotions. In the 
spiritual life, tears are viewed as a multi-faceted phenomenon (Bäumer \& Plattig, 2010b, p. 83). The healing and liberating effects of tears are described in the Christian tradition several times. In the relationship with God, tears can be part of the dialogue and prayer with God, again in terms of acceptance of one's own weakness and failures or can lead to deep insights. Crying is also important for the release of physiological tension. One religious sister reports her release of tension in dealing with spiritual dryness: "Well, it's this sadness that I have.... Yes, sometimes the tears are then also helpful to cry" (S12, 424, 426-427).

Reasoning The tendency to compare one's own experiences with those of others is another coping strategy. One's own suffering - perceived as bad and painful-then comes into perspective. For example, one brother stated that when "I meet victims of sexual abuse, accompany them and think only of 'God, what's my little bit, what I experienced there, that's just petty,' yes?" (B16, 586). Or, a sister commented, "If then, what do I know, someone's food burns, and someone gets upset about it, I can't get upset about something like that, if the world burns there,... Then-I can also get upset about some things in everyday life, but when I experienced such a situation, then some things became relative. And I would sometimes like to have this relative feeling again, when I see in religious communities how some things are so small-minded again" (S11, 217-223). By comparing their own struggles with those of others, they are able to distance from and to downgrade their problems. This can be seen as a process of cognitive reappraisal.

Recognizing a more profound meaning Looking deeper than before may be a further internal coping strategy. It requires the willingness to deal intensively with oneself: "Times of dryness, I know that feeling too. But when I discovered this depth, then I knew: This is where it goes on" (B11, 489-491). A religious sister describes experiencing an intrinsic change. It calmed her and gave her the feeling that God was with her and cared for her: "I felt something changing inside. Either sort of a message, 'I'm here after all,' and then suddenly there's calm and peace inside, and then something loosens up and then there's joy" (S3, 254-257). She viewed God as encouraging her, but only after she was prepared to perceive it. According to a brother, a religious man is encouraged not to choose the path of avoiding pain. It is important to listen to all messengers - those of light but also those of darkness and pain (B16, 632-633). It is necessary to listen to both and to understand what God wants to tell you and wants to reveal. "And then think about whether the pain wants to tell you something!... And I try to listen to those voices" (B16, 631). This again is a cognitive reappraisal strategy. A religious sister talked about her religious conviction that, especially in the difficult phases, God placed people at her side (these are also external social resources) who encouraged her and strengthened her self-confidence. She was also sure that God had given people the ability to overcome difficult times. This strengthened her self-confidence because she was convinced that God trusted in her abilities and called her to do the same: "And there it was mostly in the last then around to know, so it is right, trust yourself. According to the motto: God trusts you and then trust yourself. He has given you this ability to get through such times" (S6, 581-588).

Lack of strategies Only a few religious brothers and sisters reported not having developed or used a strategy to counteract the experience of spiritual dryness: "Well, that I would have developed serious strategies to say, 'Well, now you have to do this or that differently' [thinking], no, no" (B9, 186-187). 


\section{Internal: spiritual resources}

The second category focuses on spiritual resources that were useful in overcoming spiritual dryness. Religious attitudes and religious practices played a significant role, but social integration into the faith community with its associated social resources and relationships was seen, too. In this regard, this category overlaps the category external: social resources, but the latter is much more focused on the faith community aspect. The resources mentioned from which emotional, cognitive, and instrumental support in coping with specific problems arise are prayer in general, common prayer, silence and gathering, openness, ritualized forms of religious practice, and retreats. Catholic spirituality is of particular importance for religious brothers and sisters. For example, the German Pastoral Ministry Study found that spirituality is a significant factor in pastoral engagement, life satisfaction, and somatic and mental health (Jacobs et al., 2016).

Basic certainty in God's closeness/basic trust Cognitive trust or confidence in God's presence-even if one cannot feel God at the moment or when God seems to be distantwas a topic in many interviews. "So, yes, even if I don't notice it, he is still there somewhere. So, that is such a basic certainty that is somehow already there" $(\mathrm{B} 9,180)$. A religious sister expressed it in a similar way but highlighted an underlying message for difficult times: "God is there. He is present. He is there in every situation, in every reality, and He wants to tell me something with this reality. However, it is at the moment, I just have to, yes, listen to what he wants to tell me with it" (S9, 202). Another sister stated that even when she may have distanced herself from God, God was still available for her: "I trust that you will not go away from me, even when I am away from you, and when I do not feel you." (S2, 263-264). The moral theologian Bernhard Fraling speaks of an indirect experience of God, which is when a person interprets an experience in the light of faith and experiences God as present or co-active in this experience. Everyday experience is related to faith and is interpreted accordingly (Fraling, 1992). In many cases, moments of crisis and phases of spiritual dryness are carried out with the basic certainty that God is there. "You have experienced it, and even when you do not feel it, he is by your side" (B14, 339-340.

Prayer (life) Prayer is the expression and form of the relationship with God and thus the heart of a practical understanding of Christianity. For Christians, it is assumed to be one of the basic processes of their human existence (Thull \& Arnold, 2016). The practice of prayer within Christianity is quite diverse, ranging from private to congregational prayers, either free or with a fixed structure. The praying person encounters God both personally (with their own body) but also 'inter-bodily' in the case of community prayer (Peng-Keller, 2017, p. 14). To pray means to enter into relationship and dialogue with God. Prayer is an essential element in religious communities; as one brother said, it gives "strength to live or survive in prayer. Despite all the blows and setbacks and difficulties, prayer was always the most important thing for me" (B5, 134-136). This was confirmed by a sister: "Yes, so for me it was always prayer, and the Scriptures" (S7, 261). Prayer is difficult when one perceives that one's own prayers are fruitless, but prayer is also important as a container and structure for remaining in relationship with God.

In particular, the old psalms found in the Liturgy of the Hours seem to be enormously enriching during dry phases because they "are simply a treasure trove.... There are words and contents given to me, to which I can attach myself wonderfully, where I can really 
resonate and carry this before God. So, that is for me in my current situation rather, um, what holds me and carries me" (B14, 313-318). After her bond with God seemed to be broken, one sister tried to find a point of reference in her faith, in Psalms as well as in other texts: "Then I looked in faith, in Psalms, in texts, everywhere, where I might find an anchor that would get me out of this" (S3, 245-246). Here, these prayers are an anchor for remaining in relationship with God.

Common prayer is valued as an essential aid in countering or even counteracting the experience of spiritual dryness: "Prayer, the common prayer of the Psalms, is a certain help and preparation" (B8, 286-389). Even though the congregational prayer time was skipped due to changing priorities, it was seen as an important resource: "No, now you have to go, you have to pray with the confreres.' Yes, that's not a particularly noble argument now, but it saves you over crises and over dry spells and low points. And then you go on and find the way again, the thread again" (B3, 257-261).

However, the power of intercessory prayer and the solidarity of others are also considered (although these could also be seen as external resources): "And also with people who have accompanied me through their prayer" (B5, 160). By recourse to the traditional, interpretative certainty and orientation for action are experienced. Thus, practices such as the Jesus Prayer, meditation, reading the psalms, and intercessory prayers as well as an active testimony can promote a lively spirituality and a constructive approach to overcoming phases of spiritual dryness.

Ritualized forms of religious practice A religious community is also a community of prayer. Religious sisters and brothers celebrate their daily worship and come together to pray the Liturgy of the Hours. Prayer, adoration, and contemplation are formative times in everyday life. They offer an encounter with Christ in word and sacrament. Private contemplation and personal prayer are important additions to spiritual life and may help one cope with spiritual dryness. The constitutive moment of communal prayer was clearly stated by a brother: "Our prayer life is a very sensitive point, and if not everyone, with all their differences, attaches importance to it, then it has repercussions on the concrete house community" (B14, 250-252). The benevolence of prayers is experienced as helping to preserve routines, such as by not having to think about it further but simply being allowed to move with the flow of the execution. Accomplishing things together is perceived as a gift of loyality that helps "through such times, and for me, doing things together also helps because... that is not asked for and I don't have to decide anew every day. But I have decided once, and then it is also like that. Then I also... well, that has something to do with loyalty" (S5, 252-255).

There is an enormous amount of ritualized acts in the private as well as in the public sphere, in the profane as well as in the religious. Rituals pervade human life, and humans seem to order their lives with rituals (Hobson et al., 2018). Rituals help with learning certain things and structure certain areas and times of life. Prayer and liturgy as places of God's presence are consciously used to turn to God and to open a space of encounter with God. For (religious) Christians in particular, the celebration of the Eucharist is a central element of the practice of faith, as "there is the reconnection to faith, to Jesus Christ, the reconnection to the Eucharist, in prayer, I have considered and experienced to be very important, and I stick to that. So, that-otherwise it goes wrong” (B3, 253-260).

When one is disoriented, the attitude of openness to the chance encounter with a text can be a help, as one brother described. The texts sometimes fit everyday situations (and 
his search for support); they are relevant to the personal life and thus have an inspiring effect, "Or right now, when there is a lot that is bothering me and I am searching, 'How can I get support again?' it's pleasant for me when I am simply present in the liturgy and a sentence touches me" (B8, 392-397). Turning to Christ in daily contemplation and immersing oneself in Christ's Word gives much support in times of spiritual dryness as it may be perceived as an awaited 'response': "I felt that this gave me joy, going through the Gospel and the readings every morning, which then spoke to me" (S8, 278-279); "Or then a Bible text spoke to me that pulled me out" (S10, 303-307). The practice, which has been carried out for many years, provides security and support: "And from that point of view, this longstanding practice of entering into a relationship with God is simply also a help in dealing with it" (S5, 241-242).

Silence and collection/gathering The expressions of religious experience include not only the trusting word but also a 'sacred silence.' This is an essential element of personal prayer as well as of communal liturgy. The Danish writer and theologian Sören Kierkegaard said:

As my prayer became more attentive and inward, I had less and less to say. I finally became completely silent. I started to listen-which is even further removed from speaking. I first thought that praying entailed speaking. I then learnt that praying is hearing, not merely being silent. This is how it is. To pray does not mean to listen to oneself speaking, Prayer involves becoming silent, and being silent, and waiting until God is heard. (as cited in Halbfas, 1994, p. 139)

These contemplative elements are needed to be able to face the experience of spiritual dryness. One brother describes it as follows: "It is also enough even if I sometimes sit here and don't speak at all" (B4, 221-224). A sister said: "I have contemplation very strongly, and I also have to do it every day-or [I end up in] my crises or my dryness. The strength comes from silence" (S2, 79-81).

The moment of collection - through time-outs and phases of rest-is also described as helpful: "It [the Sacred Heart prayer] helps me to collect myself and come to rest" (B8, 314).

Religious brothers and sisters indicated that time-outs should be consciously granted. "I know two years ago or so I said: 'So I have to get out for a week, I need a week of silence, where I can sort myself out again, so that I don't get into a situation that... that does no one any good"' (S5, 304-311); "If I lack a time of prayer, time of God's presence, then I have to consciously shape and tackle that again" (B7, 141-143. Thus, phases of silent contemplation or silent prayers are seen as a resource to reconnect and to emotionally and spiritually 'refuel.' Sitting in silence means to be open to when and how God may respond.

Openness The experience of God in human life may be unavailable. Openness in spiritual life to whatever may come was seen by a brother as an opportunity to experience God's healing care and to immerse in the act of grace. "In prayer we open our hearts to God" (Rahner, 1949, p. 11) - this is all that is required on the part of humans, not only within the 'happy' times but also during the dark phases of life. Openness becomes a strategy to shape the longing for God and to also face phases of spiritual dryness: "Well, one cannot simply make faith in this sense, make it up oneself. But you can [develop] the organ [for it], if the experience-expose yourself to an experience, get ready for it" (B11, 495-500). The 
experience of spiritual dryness is interpreted as an element of life. "Well, maybe it's also a matter of getting involved in this somehow and realizing, anyway, so there is still life" (S14, 281-283).

Spiritual exercises In the search for a personal path of life and faith, individual retreats are a source for reflecting and realigning the relationship with oneself, with others, and with God. The conscious times of retreat may touch the profound structure of one's being and discover hidden and unconscious patterns of the mind and self. Facing these aspects provides a means of realizing what was lost during the daily routine, said one brother: "Sometimes I notice, when I come back from retreats or something, that suddenly something is felt again that was not addressed before.... It's good that you're getting back into the depths now', something like that." (B7, 129-131. 134-135). In this regard, a sister noticed the element of walking, which had helped her deal with spiritual dryness: "Because I do spiritual exercises, I just walk a lot. Because of this movement that is there externally and internally, I simply know: I am on the way with You! And God is a God of the way. Emmaus is a very important image for me" (S6, 480-483).

\section{External: social resources}

The third main category of strategies comprises external social resources. Phases of spiritual dryness can be managed more easily when concrete persons are available who offer help and support. The subcategories are supportive companions, spiritual guidance, community as a resource, attention to life experiences, and psychotherapeutic/psychological support. The brothers and sisters experienced exchanges and supportive interactions with others and the support of others in personal contacts as helpful. Knowledge of the intercessory prayer of others and the support of spiritual guidance were also given high priority. Entering into and cultivating interpersonal relationships and personal encounters can provide constructive approaches to coping with and overcoming spiritual dryness. These concrete relations may help to "ground" one when the relationship with the Transcendent is difficult.

Supportive companions This subcategory focuses on the social relationship dimension with persons outside the religious community. The positive experience of being supported by other people through intercessory prayer can encourage and carry one through the hardships of dry periods, as one brother stated: "There were always people who stood along this path and who approached me, who simply helped me. For example, they have made an effort for me, or they simply said, 'Here, Father..., I am praying for you' (B2, 208-211). A sister emphasized the aspect of self-assurance. Experiencing the encouragement and support of others was a great help to her, not least to strengthen her self-confidence: "I simply had people at my side who helped me during this time as they said, 'You are on the right path; you see things correctly"' (S6, 395-396).

Conversations with confidants outside the monastery, which touched on topics other than current crises, helped brothers and sisters to develop new perspectives. Gaining distance from intramonastic problems and being allowed to experience 'normality' became a coping strategy: "I have good friends with whom I can talk and with whom I 
can also consider completely different things than any crises of faith or monastery crises. Just going out for a bit, stepping out, looking at it from a distance" (B10, 282-285).

Being able to speak openly with confidants about difficulties-and also concerning the spiritual life-was experienced as a benefit: "But that probably helped me, that I could talk about it, that I no longer went with God, in the sense of having a person at my side [who listened]" (S2, 201-203). It seems that this sister did not necessarily expect an answer but appreciated someone who listened and approved of her struggles.

One sister credited God with having repeatedly provided her with companions who were an essential help in the faith journey: "Yes, I can also say that people have been sent to me again and again who have helped me along. And yes, when you then feel in retrospect that through all this struggling and the longing that is related to it, you have once again come a little closer to God, then-that is the motor that helps you along" (S9, 81-85).

In situations where our known strategies fail, it often helps to turn to those who were once in the same situation, in the same place, and can teach us based on their experiences. Turning to experienced others and profiting from their attitudes could be regarded as a further coping strategy of one religious sister, a way to gain a new perspective, not necessarily from what is said but by their authentic presence: "I do that, for example, when I feel bad, I like to go to our retirement home, because-to our older sisters.... I don't have to say much, they cheer me up again" (B12, 408-410,411-412).

Religious community Connections and relationships are essential in a religious community. Religious women and men commit themselves to a common religious life in the structure of an order and a life with people who are guided by the same fundamentals. Religious life is similar to that of a family: conversations, shared duties, and the beautiful and difficult sides of living closely together. This is challenging, supportive, and enriching-but can also be problematic as some of the conflicts within the community may affect the spiritual life, too (Büssing et al., 2020a). The high value of community and the high investment in communal processes in everyday life prove themselves in times of spiritual crisis. The community can be experienced as a support in overcoming spiritual dryness: "Well, I found the community quite supportive at that time, although I didn't say so in the community, but I thought it was good that it was there, otherwise I probably would have gone crazy right away" (S14, 159-162).

In several interviews, the support provided by the community was emphasized: "And I have to say that the community also stabilizes [in difficult times]" (B3, 381). On the one hand, the stabilizing force results from personal relationships: "There have always been brothers with whom I have lived. We have prayed together, argued together, worked together. And that, I think, has made the dryness, well, not come up so much." (B13, 155-158). On the other hand, the stabilizing effects may also result from the given structures, rhythms, and fixed prayer times within the community: "That's why I tend to think that it helps me, that is, when I'm not doing so well personally, to connect to the community or to these structures that are supported by the others" (B8, 286-288); "So, this regularity that you have in the order, it helps a lot with these things, I think" (S6, 165-167).

Retrospectively, the experience of comprehensive support from the religious community during a time of illness and the high value of being integrated into such a supportive network was described with gratitude: "During my illness, the order opened up all 
the possibilities here for me to get well again.... And it was only then that I experienced the value of the community. That's when I became aware, man, how solid and how outstanding the network of the religious community is" (B2, 286-290).

Spiritual guidance This subcategory is about the counseling approach of spiritual guidance. The focus is on encouraging a personal relationship with God. Spiritual guidance helps a person grow in their relationship with God and considers individual life issues in the context of faith development (Dienberg, 2020). Being able to make use of spiritual direction was experienced as a valuable support by a sister who stated, "Yes. Without it [spiritual direction], it (to overcome or cope with phases of spiritual dryness) would certainly have been perhaps even more difficult" $(\mathrm{S} 12,374)$.

Conversations with a spiritual guide are considered an important factor in overcoming spiritual dryness, in addition to character traits: "My longing helped me, and also my struggling again and again, maybe also a bit of my feelings of guilt, but definitely also the conversations with spiritual guides, with people who, yes, I could also speak openly with. That was a very big help for me" (S9, 221-224).

Belonging to the religious community with its personal networks was experienced as beneficial: "I sought help... from a confrere with whom I opened up, and he also understood me well, encouraged me" (B5, 172-174). Being able to talk with others about difficulties and struggles, to ask for help and to be able to trust that one would receive help within the spiritual community, was valuable to the brothers and sisters: "That is great in a religious community. I went to the respective sisters and said, 'It is this and that, and I can't get out of it.' And then the sisters helped me when they were ready to accept. That was very good for me. And since then I've always had spiritual accompaniment as well" (S12, 362-367).

Psychotherapeutic/psychological support In order to cope with a spiritual crisis, in a few cases psychological/psychotherapeutic support was used in addition to accompaniment by friends and acquaintances or working with a spiritual guide. This subcategory was added in the second phase of the study as it was mentioned by sisters only. Whether the brothers never used it or did not talk about it remains unclear. The overarching objectives of psychotherapy are "to positively influence symptoms and states of suffering as well as psychological, occupational, and psycho-social well-being and functioning" (Hofmann \& Heise, 2016, p. 62). Strengthening coping skills, self-esteem and relationship skills, development and post-maturation of a basic sense of self-worth and a stable ego structure are further treatment goals (Hofmann \& Heise, 2016, p. 62). One religious sister explained that she recognized that she needed another component in addition to a spiritual guide to cope with her spiritual dryness. She decided to seek psychotherapeutic support: "I also took advantage of psychotherapeutic treatment at one point during these times because I simply realized I can't get anywhere on the spiritual level alone" (S6, 374-376). Another religious sister went to psychological counseling and stated: "During the times when I had these professional problems, I also took, yes, therapy is too much to say now, but I had a psychological accompaniment" (S12, 360-362). Her reluctance to clearly state that she required psychological support was obvious. It seemed to be a matter of shame.

Participation in everyday life This subcategory emerged from statements in the context of a threatening illness and times of spiritual dryness. One sister addressed three key 
strategies that had helped her to cope with spiritual dryness. In addition to common prayer, conversations within the community, and the knowledge of being carried through difficulties, the possibility of participating in the congregation's everyday activities became an important support for her. Being integrated into the daily life structures and practices of the sisters and being able to participate in the familiar daily routines became a coping mechanism in a phase of life characterized by a spiritual crisis and coping with an illness: "Yes, in principle these were the two pillars and simply_which was very important for me, even in the time of my illness - that I could live the everyday life. The normal everyday life was actually one of the most important, I would say this third pillar, which is still there, in addition to prayer and in addition to the conversations that I have, or in addition to the support of the fellow sisters and other people" (S6, 505-509). Being integrated in the 'normality' of life helped her to stabilize in a time of crisis.

\section{External: other resources}

The fourth main category combines impersonal resources such as the experience of God/ the Holy Spirit as a source of help, the experience of nature, and the experience of art and music.

God/the holy spirit as help A central image of God described in this context is experiencing God as someone who attends people - a God of the Way. This is already reflected in the biblical experience: Yahweh is the God who guides and accompanies God's people. God says "I am who I am" (Exodus 3:13), still present but difficult to perceive. This image of God and the belief in a caring, loving and helpfully acting God, as described for example in the 23rd psalm, strongly characterizes the perceptions of some religious sisters and brothers and has helped them to overcome spiritual dryness: "You did not make it out of yourself alone now, but there He has brought you out of here again" (B2, 276-277). Here, God as a transcendent source is the actor.

In phases of spiritual dryness, the Holy Spirit is experienced as a support: "And yes, with the Holy Spirit, who is the third person. Then you can endure the drought—'drought, pour in life' - or the dryness. That also came to me, then, that $\mathrm{He}$ - in the moment when there is nothing left with me-that He can then revive me again" (S6, 292-296). This describes an experience that aligns well with Doris Nauer's definition of the Holy Spirit as "practical, real encounter-experience of God on earth, in the history of his creation and in each individual, even everyday human life" (Nauer, 2017, pp. 190-191).

Nature as a resource One religious sister described going out into nature consciously: "I love nature very much, I like to go out into nature, and that already does clear the head again, that already does good" (S9, 229-230). Moving around in nature was mentioned by another sister as a positive coping mechanism: "What I am then doing, what also helps me, [is] walking, in nature. I need nature, that's quite wonderful, just to walk and do something" (S12, 462-464). The sisters did not explicitly state that this buffered spiritual dryness but said that it was helpful for clearing the mind.

Creativity, art and music The third subcategory includes artistic and musical resources. Literature, music, and the expression of one's own creativity were seen as valuable 
resources for overcoming spiritual dryness. These resources offer relief and are also part of leisure time. A religious sister described how strongly she could be touched by words and images to get new impulses for her (daily) life. "Ahm, what was always important for me was to look: where does something now shine for me? That is-mostly it was words, mostly it was... or also sometimes pictures, just this cross, which was important for me" (S6, 513-516). She opened herself to what came to her by chance and touched her and regarded it as an implicit message.

Another active coping effort mentioned by one sister was writing down her own experiences, both to let them go and to be inspired: "Yes, and I also like to write. I can also write things off my chest - that I write it down, and certainly when I have new insights and new, yes, things experienced again, I like to write it down" (S9, 230-236).

Literature was also used to cope. For example, one brother talked about how books filled him with great joy, and they were like a treasure to him: "So, a book is a precious gift for me" (B5, 197).

The possibility to become creatively active and to express the experience artistically was mentioned as another way to deal with the experience of spiritual dryness and to distance oneself from the underlying pain: "And with wax crayons I once put this whole shitty situation on paper and hung it over my bed" (B16, 606-607). Likewise, processing can take place through musical expression, as experienced by a brother: "So my guitar, it's just really valuable to me when I'm so dry" (B12, 198-199).

\section{Discussion}

Results from this qualitative study indicate a rich spectrum of strategies and resources for coping with spiritual dryness. Within the 30 interviews with religious brothers and sisters, four main categories were identified: (1) internal: reflexive resources, (2) internal: spiritual resources, (3) external: social resources, and (4) external: other resources. This is principally in line with empirical data of the German Pastoral Ministry Study (Büssing et al., 2017b; Sautermeister et al., 2017) and a study of Seventh-day Adventists (Büssing et al., 2020b).

Personal resources are needed to cope with the challenges of life (Schwarzer \& Knoll, 2001). One of these is the ability to observe one's own processes of perception and action 'from a distance,' have an inner dialogue with oneself, and engage in self-referential thinking (Fröhlich-Gildhoff \& Rönnau-Böse, 2011). Also, the personal resources of enduring, patience, and self-control were found as relevant in another study, where they had a positive effect on stress in caregivers (Dalir et al., 2020). Furthermore, personal reflexive resources are essential, according to the philosophical perspective of humanism. In order for human beings to live consciously, they need self-reflection to be aware of their own values and goals and thus decision processes and thereby to improve their ability to act. A positive effect of this ability to reflect on one's own ideals, attitudes and behaviors is that it may lead "to the development of intentions to change," as stated by Greif (2008, p. 19). With respect to interviewees' coping strategies, this implies that being aware of one's own ideals, hopes, and perspectives and also one's emotional reactions to struggles and difficulties may result in processes of change and reappraisal. Arnold (2008) describes such processes figuratively when she states that in most cases it is not the "fact" that cause the difficulties "but our thinking and our feeling, which are triggered by these facts" (p. 16). This interpretation is 
quite common in stress theory, where patients learn to restructure their mindset and subsequently their reactions toward the stressor (here, the "fact"). Thereby, personal reflexivity is needed to be able to deal with difficult situations directly and to choose adequate personal coping strategies. On the other hand, self-reflection promotes one's own development and thus has a preventive character with regard to resistance that arises in the future. Thus, this intrinsic category includes a variety of different coping strategies and reactions, such as enduring, waiting, and persevering; accepting; self-reflection; allowing tears; reasoning; and recognizing a more profound meaning. Some of these may be triggered by other persons (external), resulting in insights about one's perceptions.

Spiritual resources are of great importance, particularly for religious people. This is an intrinsic resource, too. It seems that spiritual confidence or faithful perseverance may be an essential element in coping more effectively with spiritual dryness. The basic certainty of God's nearness, even if one does not perceive it, appears to be a fundamental resource that is activated in coping with spiritual dryness. In most cases, this is cognitive knowledge only, while the emotional perception of 'not feeling it' may dominate. Prayer, especially the psalms, and the cultivation of a prayer life are for some part of the problem (Büssing et al., 2020a) but nevertheless help others to endure in times of dryness and to stay in contact with God, as shown in this study. Ritualized forms of religious practice, common prayer, silence, and gathering have similar importance for some persons, while for others they are problematic (Büssing et al., 2020a, b, c). The German Pastoral Ministry Study demonstrated that spirituality plays a significant role in pastoral engagement, life satisfaction, and somatic and mental health (Jacobs et al., 2016, p. 71). Spirituality related strategies (private prayer/meditation/Scripture reading and devotion to God) were also most commonly used by Seventh-day Adventist members to cope with spiritual dryness (Büssing et al., 2020a). Thus, depending on the personal situation, the underlying causes, and the personality structure, spiritual resources may be helpful, while for others they are part of the problem.

Religiosity as well as more general spirituality is considered one of several possible resources for dealing with crises and trauma (Ano \& Pargament, 2013). One can differentiate between positive and negative religious coping, particularly when negative religious coping is related to negative mental health (Weber \& Pargament, 2014), whereas people with positive religious coping and stable beliefs seem to succeed more easily in coping with life crises (Weber \& Pargament, 2014). This resource has a two-sided effect in that one's own spirituality may stabilize one's mental health but may also negatively affect one's mental health, depending on the coping style (Weber \& Pargament, 2014). According to Pargament (1997) model, religious coping styles differ in the extent to which the relationship to God is incorporated into crisis management. Differentiated styles include faith activating, ignoring, and interactive. Religious coping allows one to draw on religious resources and employ appropriate coping strategies. In terms of spiritual dryness, when God is perceived as distant, in most cases positive religious coping strategies are chosen because God is not seen as a punishing God but as a supportive God who is still present (see the subcategory basic certainty in God's closeness/ basic trust). However, this does not exclude the possibility that one may not 'feel' it. It is interesting that, apart from prayer life, interviewees also mentioned times of silence and collection/ gathering. This implies an openness toward God's own ways of reacting and responding. The religious brothers and sisters did not press for a reaction but waited in patience. This resembles the Old Testimony story of Jacob fighting the whole night with the angel (as the representative of God) until God gave his blessing (Genesis 32:22-32).

Our findings underline the importance of social resources, too. One of the five coping reactions identified by Lazarus and Folkman (1984) is the search for social support. Our third main category covers social support. In particular, perceived social support, as a 
psychosocial resource, can have an influence on various aspects of health as it may impact and improve psychological well-being, reduce stress, and reduce the impact of adverse living conditions (Berkman \& Glass, 2000; Borgmann et al., 2017; Ditzen \& Heinrichs, 2007; Martin, 2000; Schwarzer \& Knoll, 2007; Uchino, 2004; Uchino et al., 2011). Various interlocutors and networks within but also outside the religious community were chosen by the interviewees during phases of spiritual dryness. Frequently mentioned were supportive companions, (selected members of the) religious community, and professional supporters (spiritual guides or psychotherapeutic/psychological accompaniment). The importance of emotional support through understanding, attention, and feeling supported and comforted was mentioned several times. Such conversations were of great help as the brother or sister was allowed to speak frankly about their experience of spiritual dryness and the listening person showed understanding instead of blaming the struggling person as 'weak in faith' or too lazy in their religious practice. There was a wish for greater openness on the part of the interlocutors and an understanding of those who had themselves experienced phases of spiritual dryness and had sought and (at least partially) found strategies for dealing with it.

The fourth category refers to various external other resources, which include God and Holy Spirit as transcendent sources of help, being in nature, and creativity, art and music (in terms of cultural and aesthetic elements). The health-supporting effect of experiencing nature has been the focus of research in several studies (Ensinger, 2016; Gebhard, 2005, 2010, 2020). Natural spaces have an invigorating effect and can contribute to recovery from mental fatigue and stress (Kaplan, 2001), may have a positive influence on one's recovery and well-being, and can help to sort oneself and one's thoughts. Interviewees mentioned literature, music, creativity, and experiencing nature as both needs and resources. They experienced these in receptive and productive ways. The positive influence of listening to music, as well as making music oneself, has been researched (Horden, 2017; Lynar et al., 2017; Thoma et al., 2013; Trappe, 2017, 2020). The same applies to reading books or writing (Bavishi et al., 2016; Billington, 2019). The positive effect of reading and making music on well-being can be attributed to both the relaxation effect and the process of distancing oneself from one's life situation.

The transcendent component among these cultural and creative practices, in that interviewees experienced God/the Holy Spirit as a help, also forms an aspect within this category, which shows a partial overlap with the intrinsic subcategory basic certainty in God's closeness/basic trust.

\section{Conclusion}

In this qualitative study of religious brothers and sisters, we identified various strategies and resources for coping with phases of spiritual dryness. The basic categories are intrinsic and extrinsic. Effective coping behavior depends on the strategies available and the individual's flexibility to apply them adequately, not on any particular strategy (Kohlmann, 2003). Thus, the variety of resources and their implementation as they deal with phases of spiritual dryness reflects the heterogeneity of the interviewees, as well. What one person found to be an effective strategy might not apply to another. The strategies have to be chosen according to individual coping styles (which takes into account not only the underlying triggers of spiritual dryness but also personality characteristics, self-efficacy expectations, introversion and extroversion, optimistic or pessimistic attitude, etc.) and the preferred strategies (i.e., emotional or problem-oriented or avoidance; Sahler and Carr (2009). 
Different coping skills can be used depending on the situation. Sometimes it is appropriate to change own attitudes, expectations, and behaviors and sometimes to endure in silence or to talk with others and to be reassured about one's experience; other times adherence to daily routine and work or walks in nature are best. A mix of different strategies might be appropriate. Spiritual dryness, a spiritual crisis combined with feelings of the absence from God and doubt, can be experienced by even the most faithful people. The fact that withdrawal and unavailability are an indissoluble part of the nature of God is a tension that many believers have had to endure and is inherent in the biblical image of God. Spiritual dryness is in many cases the inevitable experience of those who persevere in their efforts to grow closer to God (Büssing \& Dienberg, 2019). There is also no reason to condemn the occurrence of spiritual dryness, to label it as disbelief or to degrade the person with such an experience. Rather, the term 'crisis' also has a positive connotation as an opportunity and a chance, "the successful overcoming of which is associated with a strengthened sense of self" (Burgess \& Baldwin, 1981); out of the experience of spiritual dryness can grow a more mature faith and deeper insight and the realization that God as "near-far" ultimately remains an attractive mystery (Nauer, 2017, p. 204).

\section{Limitations}

The results were derived from Catholic religious brothers and sisters living in Germany. It may be that perceptions of religious people from other countries differ and that additional categories or subcategories could be found. Similar research is thus encouraged.

Funding Open Access funding enabled and organized by Projekt DEAL.

Open Access This article is licensed under a Creative Commons Attribution 4.0 International License, which permits use, sharing, adaptation, distribution and reproduction in any medium or format, as long as you give appropriate credit to the original author(s) and the source, provide a link to the Creative Commons licence, and indicate if changes were made. The images or other third party material in this article are included in the article's Creative Commons licence, unless indicated otherwise in a credit line to the material. If material is not included in the article's Creative Commons licence and your intended use is not permitted by statutory regulation or exceeds the permitted use, you will need to obtain permission directly from the copyright holder. To view a copy of this licence, visit http://creativecommons.org/licenses/by/4.0/.

\section{References}

Ano, G. G., \& Pargament, K. I. (2013). Predictors of spiritual struggles: An exploratory study. Mental Health, Religion \& Culture, 16(4), 419-434. https://doi.org/10.1080/13674676.2012.680434

Arnold, P. (2008). Führen mit Gefühl. Eine Anleitung zum Selbstcoaching mit einem Methoden-ABC [Leading with feeling: A guide to self-coaching with an ABC of methods]. Dr. Th. Gabler.

Bäumer, R., \& Plattig, M. (Eds.). (2010a). Dunkle Nacht und Depression: Geistliche und psychische Krisen verstehen und unterscheiden [Dark night and depression: Understand and distinguish spiritual and psychological crises]. Grünewald.

Bäumer, R., \& Plattig, M. (Eds.). (2010b). Die Gabe der Tränen. Geistliche und psychologische Aspekte des Weinens [The gift of tears: Spiritual and psychological aspects of crying]. Grünewald.

Bavishi, A., Slade, M. D., \& Levy, B. R. (2016). A chapter a day: Association of book reading with longevity. Social Science \& Medicine, 164, 44-48. https://doi.org/10.1016/j.socscimed.2016.07.014 
Berkman, L. F., \& Glass, T. (2000). Social integration, social networks, social support, and health. Social Epidemiology, 1, 137-173.

Billington, J. (Ed.). (2019). Reading and mental health (1st ed.). Palgrave.

Borgmann, L.-S., Rattay, P., \& Lampert, T. (2017). Soziale Unterstützung als Ressource für Gesundheit in Deutschland [Social support as a resource for health in Germany]. Journal of Health Monitoring, 2(4), 117-122. https://doi.org/10.17886/RKI-GBE-2017-120

Burgess, A. W., \& Baldwin, B. A. (1981). Crisis intervention theory and practice : a clinical handbook. Prentice-Hall.

Büssing, A. (2019). Geistliche Trockenheit bei Seelsorgern und Ordens-Christen. [Spiritual dryness in pastoral workers and religious]. In A. Büssing \& T. Dienberg (Eds.), Geistliche Trockenheit—empirisch, theologisch, in der Begleitung [Spiritual dryness: Empirically, theologically, in the accompaniment] (pp. 79-103). Aschendorff.

Büssing, A., Baumann, K., Jacobs, C., \& Frick, E. (2017a). Spiritual dryness in Catholic priests: Internal resources as possible buffers. Psychology of Religion and Spirituality, 9, 46-55. https://doi.org/10. 1037/rel0000063

Büssing, A., Beerenbrock, Y., Gerundt, M., \& Berger, B. (2020a). Triggers of spiritual dryness: Results from qualitative interviews with religious brothers and sisters. Pastoral Psychology, 69, 99-117.

Büssing, A., \& Dienberg, T. (Eds.). (2019). Geistliche Trockenheit-empirisch, theologisch, in der Begleitung. Begleitung [Spiritual dryness: Empirically, theologically, in the accompaniment]. Aschendorff.

Büssing, A., \& Gerundt, M. (2020). Geistliche Trockenheit-eine Projektbeschreibung. [Spiritual dryness: A description of the project]. Geist Und Leben, 93, 358-364.

Büssing, A., Günther, A., Baumann, K., Frick, E., \& Jacobs, C. (2013). Spiritual dryness as a measure of a specific spiritual crisis in Catholic priests: Associations with symptoms of burnout and distress. Evidence-Based Complementary and Alternative Medicine, 246797. https://doi.org/10.1155/2013/246797

Büssing, A., Sautermeister, J., Frick, E., \& Baumann, K. (2017b). Reactions and strategies of German Catholic priests to cope with phases of spiritual dryness. Journal of Religion and Health, 56, 1018-1031.

Büssing, A., Starck, L., \& van Treeck, K. (2020b). Experience of spiritual dryness and acedia symptoms in Seventh-day Adventists. Journal of Religion \& Health, 60(2), 1261-1280. https://doi.org/ 10.1007/s10943-020-01092-7

Büssing, A., Starck, L., \& van Treeck, K. (2020c). Strategies to cope with phases of spiritual dryness in Seventh-day Adventists. Journal of Religion and Health, 60, 1281-1304. https://doi.org/10.1007/ s10943-020-01093-6

Dalir, Z., Heydari, A., Kareshki, H., \& Manzari, Z. S. (2020). Coping with caregiving stress in families of children with congenital heart disease: A qualitative study. International Journal of Community Based Nursing and Midwifery, 8(2), 127-139.

Dienberg, T. (Ed.). (2020). Geh deinen Weg vor mir . ... Geistliche Begleitung und Wegbegleitung [Go your way ahead of me. . . : Spiritual guidance and accompaniment] Aschendorff.

Ditzen, B., \& Heinrichs, M. (2007). Psychobiologische Mechanismen sozialer Unterstützung. Ein Überblick [Psychobiological mechanisms of social support: An overview]. Zeitschrift Für Gesundheitspsychologie, 15, 143-157. https://doi.org/10.1026/0943-8149.15.4.143

Durà-Vilà, G. (2017). Sadness, Depression, and the Dark Night of the Soul. Transcending the Medicalisation of Sadness. Jessica Kingsley Publishers.

Ensinger, K. (2016). Achtsamkeit, Naturerleben und die Erfahrung von Erholung [Mindfulness, experiencing nature, and the experience of recreation]. Umweltpsychologie, 20, 95-111.

Fraling, B. (1992). Geistliche Erfahrungen machen. Spiritualität im Seelsorgeverbund [Spiritual experiences: Spirituality in the pastoral network]. Reihe Perspektiven für die Seelsorge (Vol. 7). Würzburg.

Fröhlich-Gildhoff, K., \& Rönnau-Böse, M. (2011). Resilienz (2nd rev. ed.). Ernst Reinhardt.

Gebhard, U. (2005). Naturverhältnis und Selbstverhältnis. In M. Gebauer \& U. Gebhard (Eds.), Naturerfahrung. Wege zu einer Hermeneutik der Natur [Experiencing nature: Ways to a hermeneutics of nature] (pp. 144-178). Graue Edition.

Gebhard, U. (2010). Wie wirken Natur und Landschaft auf Gesundheit, Wohlbefinden und Lebensqualität? [How do nature and landscape affect health, well-being, and quality of life?]. In Bundesamt für Naturschutz (Ed.), Naturschutz \& Gesundheit (pp. 22-28). Bonn.

Gebhard, U. (2020). Kind und Natur. Die Bedeutung der Natur für die psychische Entwicklung [Child and nature: The importance of nature for psychological development] (5th ed.) Springer. 
Gerundt, M., \& Büssing, A. (2020). Qualitative Untersuchung zur Geistlichen Trockenheit bei Ordensmännern, Konzept, erste Ergebnisse und Ausblick [Qualitative study on spiritual dryness of religious brothers: Concept, first results, and outlook]. Ordenskorrespondenz, 1, 43-51.

Greif, S. (2008). Coaching und ergebnisorientierte Selbstreflexion. [Coaching and results-oriented selfreflection]. Hogrefe.

Halbfas, H. (1994). Der Sprung in den Brunnen. Eine Gebetsschule [The leap into the well: A school of prayer] (12th ed.) Patmos.

Hendriks, M. C. P. (2005). On the functions of adult crying: the intrapersonal and interpersonal consequences of tears. Unpublished dissertation, Niederlande.

Hobson, N. M., Schroeder, J., Risen, J. L., Xygalatas, D., \& Inzlicht, M. (2018). The psychology of rituals: An integrative review and process-based framework. Personality and Social Psychology Review, 22(3), 260-284.

Hofmann, L., \& Heise, P. (Eds.) (2016). Spiritualität und spirituelle Krisen. Handbuch zu Theorie, Forschung und Praxis [Spirituality and spiritual crises: Handbook of theory, research, and practice]. Schattauer.

Horden, P. (Ed.). (2017). Music as medicine: The history of music therapy since antiquity. Routledge.

Ignatius of Loyola. (1914). The spiritual exercises of St. Ignatius of Loyola (E. Mullan, Trans.). Christian Classics Ethereal Library. http://www.ccel.org/ccel/ignatius/exercises.html.

Jacobs, C., Frick, E., Büssing, A., Boháč, V., \& Koch, A. (2016). Die Ordensleute in der Seelsorgestudie. [The religious in the German Pastoral Ministry Study]. Ordenskorrespondenz, 57, 67-82.

John of the Cross. (1959). Dark night of the soul (E. A. Peers, Trans.). Christian Classics Ethereal Library. https://ccel.org/ccel/j/john_cross/dark_night.html.

John of the Cross. (1962). Ascent of Mount Carmel (E. A. Peers, Trans.). Christian Classics Ethereal Library. https://ccel.org/ccel/j/john_cross/ascent.html.

Kaplan, S. (2001). Meditation, restoration and the management of mental fatigue. Environment and Behavior, 33, 480-506.

Kluitmann, K. (2008). “Die Letzte macht das Licht an?” - Eine psychologische Untersuchung zur Situation junger Frauen in apostolisch-tätigen Ordensgemeinschaften in Deutschland ["The last one turns on the light?" - A Psychological Study of the Situation of Young Women in Apostolic religious communities in Germany] (2nd ed.). dialogverlag.

Kohlmann, C.-W. (2003). Gesundheitsrelevante Persönlichkeitsmerkmale [Health-relevant personality traits]. In M. Jerusalem \& H. Weber (Eds.), Psychologische Gesundheitsförderung. Diagnostik und Prävention (pp. 39-55). Hogrefe.

Lazarus, R., \& Folkman, S. (1984). Stress, Appraisal, and Coping. Springer.

Leibold, H. (2019). Er gewährt sich im Entziehen. In A. Büssing \& T. Dienberg (Eds.), Geistliche Trockenheit. Empirisch, theologisch, in der Begleitung [Spiritual dryness: Empirically, theologically, in the accompaniment] (pp. 237-247). Aschendorff.

Lynar, E., Cvejic, E., Schubert, E., \& Vollmer-Conna, U. (2017). The joy of heartfelt music: An examination of emotional and physiological responses. International Journal of Psychophysiology, 120, 118-125.

Martin, M. (2000). Individuelle Ressourcen und die Bewältigung von Belastungen im mittleren und höheren Erwachsenenalter [Individual resources and coping with stress in mid and late adulthood]. In P. Martin, K. U. Ettrich, U. Lehr, D. Roether, M. Martin, \& A. Fischer-Cyrulies (Eds.), Aspekte der Entwicklung im mittleren und höheren Lebensalter [Aspects of development in mid and older age] (pp. 98-115). Darmstadt.

May, G. G. (2003). The dark night of the soul: A psychiatrist explores the connection between darkness and spiritual growth. HarperOne.

Mayring, P. (2008). Qualitative Inhaltsanalyse. Grundlagen und Techniken.

Nauer, D. (2017). Gott. Woran glauben Christen? Verständlich erläutert für Neugierige [God. What do Christians believe in? Explained in an understandable way for the curious]. Stuttgart.

Ott, E. (1982). Depression? Die dunkle Nacht der Seele [Depression? Dark night of the soul]. Novalis Verlag.

Pargament, K. I. (1997). The psychology of religion and coping: Theory, research, practice. Guilford Press.

Peng-Keller, S. (Ed.). (2017) Gebet als Resonanzereignis. Annäherungen im Horizont von Spiritual Care. [Prayer as a resonance phenomenon. An approach within the horizon of spiritual care.] Vandenhoeck \& Ruprecht. https://doi.org/10.13109/9783788732301

Pontikos, E. (2007). Über die acht Gedanken [The eight thoughts]. Beuroner Kunstverlag.

Rahner, K. (1949). Von der Not und dem Segen des Gebetes. [About the need for and blessing of prayer]. Rauch.

Sahler, O. J. Z., \& Carr, J. E. (2009). Coping strategies. In W. B. Carey, W. L. Coleman, H. M. Feldman, A. C. Crocker, \& E. R. Elias (Eds.), Developmental-behavioral pediatrics (4th ed., pp. 491-496). https:// doi.org/10.1016/B978-1-4160-3370-7.00050-X 
Sautermeister, J., Frick, E., Büssing, A., \& Baumann, K. (2017). Wenn die Sinnquelle zu versiegen droht. Erfahrungen mit spiritueller Trockenheit und Wege ihrer Bewältigung aus der Sicht katholischer Priester [When the source of meaning threatens to dry up. Experiences with spiritual dryness and ways of coping with it from the perspective of Catholic priests]. Spiritual Care, 6(2). https://doi.org/10. 1515/spircare-2016-0240

Schwarzer, R., \& Koll, N. (2001). Personale Ressourcen im Alter (Personal resources in aging). In Deutsches Zentrum für Altersfragen (Eds.), Personale, gesundheitliche und Umweltressourcen im Alter [Personal, health, and environmental resources in old age]. VS Verlag für Sozialwissenschaften (pp.11-93). https://doi.org/10.1007/978-3-663-11019-4_3

Schwarzer, R., \& Knoll, N. (2007). Functional roles of social support within the stress and coping process: A theoretical and empirical overview. International Journal of Psychology, 42, 243-252. https://doi. org/10.1080/00207590701396641

Sudbrack, J. (1982). Meditation-Gemeinschaft-Mystik-Bittgebet [Meditation-CommunityMysticism-Supplication]. In A. Rotzetter (Ed.), Geist und Kommunikation [Spirit and communication] (pp. 111-161). Seminar Spiritualität 4. Benziger.

Thoma, M. V., La Marca, R., Brönnimann, R., Finkel, L., Ehlert, U., \& Nater, U. M. (2013). The effect of music on the human stress response. PLoS One, 8(8), 1-12. https://doi.org/10.1371/journal.pone. 0070156

Thull, P., \& Arnold, M. (Eds.). (2016). Theologie und Spiritualität des Betens: Handbuch Gebet [Theology and spirituality of prayer: Handbook of prayer]. Herder.

Trappe, H.-J. (2017). Musik und Herz: Was ist gesichert, was nicht, was ist neu? [What is verified, what is not, what's new?] Der Kardiologe, 11, 486-496.

Trappe, H.-J. (2020). Effekte von Musik in der Intensivmedizin [Effects of music in intensive care medicine]. Med Klin Intensivmed Notfmed. https://doi.org/10.1007/s00063-020-00733-9

Tugade, M. M., Fredrickson, B. L., \& Feldman Barrett, L. (2004). Psychological resilience and positive emotional granularity: Examining the benefits of positive emotions on coping and health. Journal of Personality, 72(6), 1161-1190. https://doi.org/10.1111/j.1467-6494.2004.00294.x

Uchino, B. N. (2004). Social support and physical health: Understanding the health consequences of relationships. Yale University Press.

Uchino, B. N., Carlisle, M., Birmingham, W., \& Vaughn, A. A. (2011). Social support and the reactivity hypothesis: Conceptual issues in examining the efficacy of received support during acute psychological stress. Biological Psychology, 86(2), 137-142. https://doi.org/10.1016/j.biopsycho.2010.04.003

Weber, S. R., \& Pargament, K. I. (2014). The role of religion and spirituality in mental health. Current Opinion in Psychiatry, 27(5), 358-363. https://doi.org/10.1097/YCO.0000000000000080 PMID: 25046080 .

Wilmer, H. (2018). Hunger nach Freiheit: Mose-Wüstenlektionen zum Aufbrechen [Hunger for freedom: Moses-Desert lessons for setting out]. Herder.

Publisher's Note Springer Nature remains neutral with regard to jurisdictional claims in published maps and institutional affiliations. 